\title{
Short Communication: Morphological diversity and the addition of golden snail protein: Its effect on flavonoid content on Echinacea purpurea
}

\author{
WINA CHANDRA FERDYANA ${ }^{1}$, YULI WIDIYASTUTI ${ }^{2}$, BAMBANG PUJIASMANTO ${ }^{3}$, \\ AMALIA TETRANI SAKYA ${ }^{1,3}$, AHMAD YUNUS ${ }^{3,4, \bullet}$ \\ ${ }^{1}$ Agronomy Graduate Program, Faculty of Agriculture, Universitas Sebelas Maret. Jl. Ir. Sutami 36A, Surakarta 57126, Central Java, Indonesia \\ ${ }^{2}$ Research and Development Center for Medicinal Plant and Traditional Medicines. J1. Raya Lawu No. 11, Tawangmangu, Karanganyar 57792, \\ Central Java, Indonesia \\ ${ }^{3}$ Department of Agrotechnology, Faculty of Agriculture, Universitas Sebelas Maret. J1. Ir. Sutami 36 A, Surakarta 57126, Central Java, Indonesia. \\ Tel./fax.: +62-271-637457, `email: yunus.uns7@yahoo.com \\ ${ }^{4}$ Center of Biotechnology and Biodiversity, Universitas Sebelas Maret. Jl. Ir. Sutami 36A, Surakarta 57126, Central Java, Indonesia
}

Manuscript received: 3 November 2021. Revision accepted: 9 December 2021.

\begin{abstract}
Ferdyana WC, Widiyastuti Y, Pujiasmanto B, Sakya AT, Yunus A. 2021. Short Communication: Morphological diversity and the addition of golden snail protein: Its effect on flavonoid content on Echinacea purpurea. Biodiversitas 23: 62-66. Echinacea purpurea is a subtropical medicinal plant that contains flavonoids. Flavonoids function as antioxidants and immunomodulators. However, information on the method to increase flavonoid content in E. purpurea is still limited. The golden snail protein increases flavonoid content. The purpose of this study was to determine the best accession and optimal concentration of golden snail protein on biomass production and flavonoid content in E. purpurea. The study used a Factorial Completely Randomized Design (CRD). The first factor was three accessions of E. purpurea (A1, A2, A3); the second factor was 5 levels of the addition of golden snail protein $(0 \mathrm{~mL} / \mathrm{L} / \mathrm{week}$, $10 \mathrm{~mL} / \mathrm{L} /$ week, $20 \mathrm{~mL} / \mathrm{L} /$ week, $30 \mathrm{~mL} / \mathrm{L} /$ week, and $40 \mathrm{~mL} / \mathrm{L} /$ week). There were differences in morphological characters of three $E$. purpurea accessions, i.e., stem and the shape of the flower crown. Accession 2 had the highest flavonoid content except for the 10 $\mathrm{mL} / \mathrm{L} /$ week treatment. The highest increase in flavonoid content in three accessions was obtained in the treatment of $10 \mathrm{~mL} / \mathrm{L} / \mathrm{week}$ gold snail protein by $19 \%$ flavonoid content compared to control treatment $(0 \mathrm{~mL} / \mathrm{L} / \mathrm{week})$. The concentration of $0 \mathrm{~mL} / \mathrm{l} / \mathrm{week}$ or control had the lowest flavonoid content.
\end{abstract}

Keywords: Accession, Echinacea purpurea, flavonoid, golden snail protein

\section{INTRODUCTION}

Echinacea purpurea $\mathrm{L}$. is a subtropical plant originating from North America (Bodinent et al. 2002) and was first cultivated in Indonesia in 1998 (Rahardjo 2000). E. purpurea produces various secondary metabolites, namely caffeic acid derivatives, phenols, flavonoids, etc. $E$. purpurea is used as one of the raw materials for herbal medicines (Lee et al. 2010). Flavonoids are secondary metabolites produced by $E$. purpurea that have the immunomodulatory or antioxidant activity, and function to maintain human body resistance (Aarland et al. 2017).

In Indonesia, $E$. purpurea has not been widely cultivated. The Center for Research and Development of Medicinal Plants and Traditional Medicines is also still studying the cultivation of E. purpurea. Many drugs, pharmaceutical, and herbal medicine manufacturers in Indonesia also import E. purpurea simplicia as raw material for their processed products (Rahardjo 2005). Information on standardization in cultivation and increasing secondary metabolites content of E. purpurea is also still very limited in Indonesia.
The addition of golden snail protein has been proven to improve cultivation and total flavonoid content. The golden snail was one of the pests that cause damage to rice crops, causing losses to farmers, however, the golden snail contains a fairly high crude protein, ranging from $18.33 \%$ (Hertrampf and Piedad-Pascual 2000) to $86.36 \%$ (Jintasataporn et al. 2014). The golden snail protein could be extracted and used as liquid organic fertilizer. The protein of golden snails undergoes a nitrogen fixation process, followed by a degradation process into amino acids. Plants absorb $\mathrm{NO}_{3}^{-}$reduced to $\mathrm{NO}_{2}^{-}$by Nitrate Reductase. Then some $\mathrm{NO}_{2}^{-}$will be reacted enzymatically with glutathione and $\mathrm{NH}_{4}{ }^{+}$, and some $\mathrm{NO}_{2}{ }^{-}$will be transported to chloroplasts to form $\mathrm{NH}_{4}{ }^{+}$. The $\mathrm{NH}_{4}{ }^{+}$is then assimilated into amino acids in a series of reactions facilitated by a series of enzymes (Frungilla et al. 2014). The use of liquid organic fertilizer based on golden snail protein can increase the yield of E. purpurea quantitatively and qualitatively (Hajagha et al. 2019). The purpose of this study was to determine the best accession and optimal concentration of golden snail protein on biomass production and flavonoid content in E. purpurea. 


\section{MATERIALS AND METHODS}

\section{Plant materials}

Three accessions of E. purpurea (A1, A2, and A3) used in this study were from the collection of the Center for Research and Development of Traditional Medicinal and Medicinal Plants (B2P2TOOT) Tawangmangu, Karanganyar, Central Java, Indonesia which had different morphological characteristics.

\section{Experimental design}

The study was conducted at the Jumantono screen house, Karanganyar, Central Java, Indonesia from April to August 2020. The experimental design used was a Completely Randomized Design (CRD) with a factorial pattern consisting of 2 factors. The first factor was 3 accessions of E. purpurea (A1, A2, and A3). The second factor was 5 levels of the addition of golden snail protein, i.e., (P0: $0 \mathrm{~mL} / \mathrm{L} / w e e k ; \quad \mathrm{P} 1: 10 \mathrm{~mL} / \mathrm{L} /$ week; P2: 20 mL/L/week; P3: 30 mL/L/week; P4: 40 mL/L/week). Each treatment had 4 replications, and in total there were 60 experimental units.

\section{Field experimental procedure}

\section{Preparation of golden snail protein}

The golden snail protein-based liquid organic fertilizer was made based on the method from Andriani (2019) as follows, the golden snail was boiled for approximately 15 20 minutes, then the shell was separated from the golden snail meat. After that, the golden snail meat was mashed using a blender. Meanwhile, 2 jerry cans (5 liters) were prepared and each jerry can be filled with 4 liters of coconut water, $500 \mathrm{~mL}$ of molasses, $160 \mathrm{~mL}$ of EM4, and 1 $\mathrm{kg}$ of mashed golden snail meat. Stir until homogenous then cover tightly with an insulating adhesive. The jerry can cap is perforated to attach a small hose with a diameter of $1 \mathrm{~cm}$ hose that is connected to a mineral water bottle. The bottle was half-filled with water to reduce gas in the jerry can. The fertilizer mixture was fermented for approximately 15 days. Protein analysis was carried out using the Kjeldahl method. The protein yield is $22 \%$.

\section{Treatment of golden snail protein}

One and half-month-old seedlings of three accessions of E. purpurea were obtained from the Center for Research and Development of Medicinal Plants and Traditional Medicines. The transplanted seedlings should have at least 3 true leaves, and be treated with golden snail protein once a week.

\section{Harvest}

Echinacea purpurea was harvested at 120 DAP (days after planting). The plants were weighed to obtain fresh weight. After weighing E. purpurea plants were dried at room temperature for 7 days followed by drying in an oven at $50^{\circ} \mathrm{C}$ to constant dry weight.

\section{Analysis of herb extract}

Dried E. purpurea were ground into powder. Five g of plant powder was weighed as the initial sample weight and then macerated with $50 \mathrm{~mL}$ of $70 \%$ ethanol for 3 days. After the maceration process, it was filtered and the filtrate was put into a cup that had been weighed previously as the empty weight of the cup and dried in the oven at $50^{\circ} \mathrm{C}$. The weight of the extract was calculated by subtracting the final weight of the cup from the empty weight of the cup (Research and Development Center of Medicinal Plants and Traditional Medicines 2018). The percentage of $E$. purpurea extract was calculated using the formula:

$$
r(\%)=\sqrt{-} \times 100
$$

Where:

$\mathrm{r}:$ Percentage of extracts $(\%)$

$\mathrm{x}:$ Weight of herbal extract $(\mathrm{g})$

$\mathrm{y}:$ Initial sample weight $(\mathrm{g})$

\section{Analysis of total flavonoid content (TFC)}

Analysis of total flavonoid content was carried out using the Aluminum chloride colorimetric method from Chang et al. (2002) with a slight modification. One hundred $\mathrm{mg}$ of concentrated extract was dissolved in $70 \%$ ethanol to a volume of $10 \mathrm{~mL}$, then sonicated for 15 minutes and precipitated overnight. Four $\mathrm{mL}$ extract was put in the oven at $50^{\circ} \mathrm{C}$, then diluted with $8 \mathrm{~mL}$ of methanol, then sonicated for 15 minutes and precipitated overnight. Flavonoid testing was carried out as follows: Solution 1:0.2 mL of extract added with $4.8 \mathrm{~mL}$ of aquabidest. Solution 2: $0.2 \mathrm{~mL}$ of extract added with $1 \mathrm{~mL}$ of $\mathrm{AlCl}_{3}$ and $3.8 \mathrm{~mL}$ of aquabidest. Solution and 2 were incubated for 15 minutes. The first sample solution was read at the wavelength of $415 \mathrm{~nm}$ using a UV-Vis Spectrophotometer. A standard curve using quercetin solution was made by pipetting $2 \mathrm{~mL}$ of the second sample solution. After that, the absorbance value was read at the maximum wavelength and operating time of the first sample solution. The quercetin concentration was calculated by the curve equation $y=0.0078 x+0.0427$, the $\mathrm{Y}$ value was the standard absorbance curve and the $\mathrm{X}$ value was the quercetin concentration $(\mathrm{mg} / \mathrm{L})$. The accumulation of flavonoids in the extract was calculated using the formula:

$$
\mathrm{F}=\frac{\mathrm{C} \times \mathrm{V} \times \mathrm{FP} \times 10^{-3}}{\mathrm{M}} \times 100
$$

Where:

$\mathrm{F}$ : Total flavonoid content $(\%)$

$\mathrm{C}:$ Quercetin concentration $(\mathrm{mg} / \mathrm{L})$

$\mathrm{V}$ : Extract volume (L)

FP : Dilution factor

M : Sample weight (mg)

\section{Data analysis}

Qualitative data as morphological diversity were analyzed descriptively. Quantitative data was obtained from the average of each observation based on the available graphs. 


\section{RESULTS AND DISCUSSION}

\section{Morphological diversity}

Morphological characteristics were observed to determine certain characteristics of the accessions of $E$. purpurea after being treated with golden snail protein. The differences in morphological characters of three $E$. purpurea accessions were in the color of the stem (Figure 1 ), the shape of the flower crown (Figure 2), and the leaf shape (Figure 3 ).
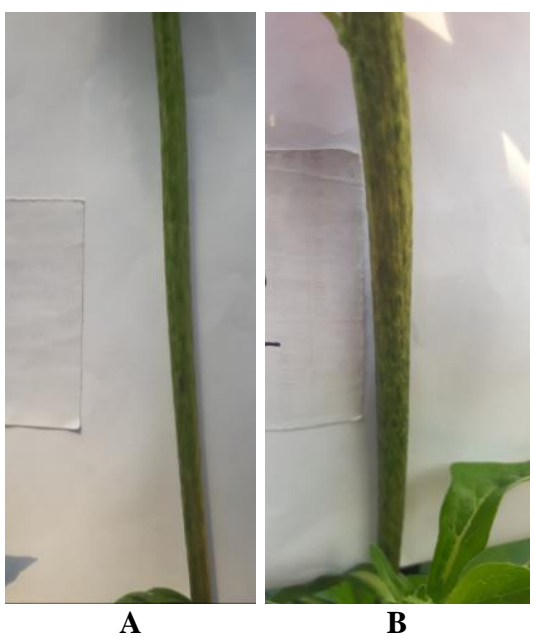

$\mathbf{B}$

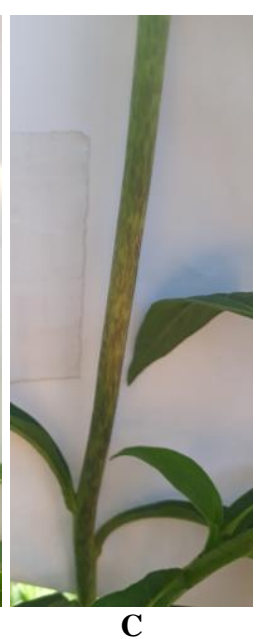

C
Figure 1. Stems morphology of three Echinacea purpurea accession. A: Accession 1. B: Accession 2. C: Accession 3

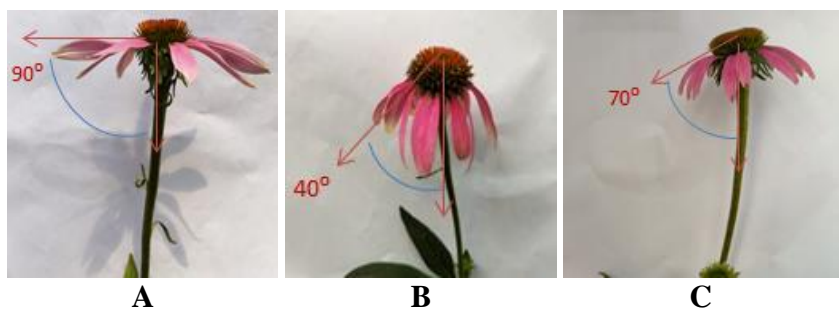

Figure 2. Flowers morphology of three Echinacea purpurea accession. A: Accession 1. B: Accession 2. C: Accession 3

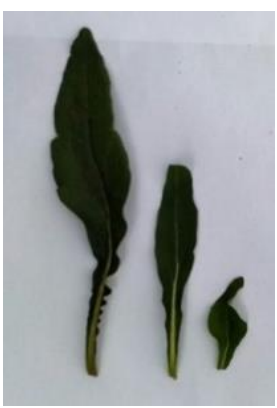

A

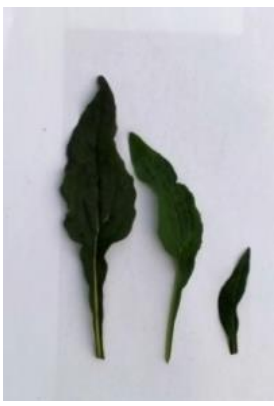

B

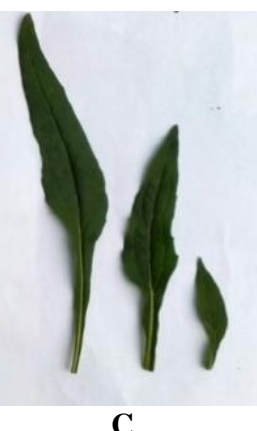

C
Figure 3. Leaf morphology of three Echinacea purpurea accession. A: Accession 1. B: Accession 2. C: Accession 3
Morphological stem of three accessions of E. purpurea

The stem morphology of three E. purpurea accessions was different. Accession 1 has light green stems with green spots, while Accession 2 has green stems with dark green spots. Accession 3 has a different stem color and is more conspicuous than Accession 1 and Accession 2, which has a green stem color with dark purple spots. The differences in stem color can be influenced by the surrounding environment, the nutrients or fertilizers applied, and genetic factors. According to Allen (2010), plant morphology such as the color or shape of plant stems can be influenced by metabolic processes in plants and external factors such as microclimate which includes temperature, humidity, stress, environmental changes.

Morphological flower of three accessions of E. purpurea

The floral morphological characters of the three E.purpurea accessions also varied. Accession 1 has a flower crown that is almost parallel or forms a right angle $\left(90^{\circ}\right)$ from the flower stalk, while Accession 2 has a striking flower crown shape, namely the crown is bent downwards or forms an angle of approximately $40^{\circ}$ from the flower stalk. Accession 3 has a crown shape that is not too bent down or forms an angle of approximately $70^{\circ}$ from the flower stalk. In line with Shidiq et al. (2020) that the agronomic and morphological diversity of E. purpurea is also influenced by cross-pollination and produces $E$. purpurea seeds with different morphological characters from the parent. Previous studies by Choirunnisa et al. (2021), showed that propagation using seeds can produce morphological variations of stem color, flower shape, and new leaves that are different from the morphological characters of the parent.

\section{Morphological leaf of three accessions of E. purpurea}

The three E. purpurea accessions studied had dark green leaves. Accession 1 has an elongated leaf shape with wavy leaf edges and blunt leaf tips. Accessions 2 and 3 had the same leaf shape, which was elongated with pointed leaf edges and pointed leaf tips. In line with the research of Shidiq et al. (2020), accessions 2 and 3 of E. purpurea had dark green leaf color with curved, serrated, and pointed leaf edges. Indentation on the edges of young leaves is not visible but is visible on mature leaves. The morphological character of the leaf shape in the E. purpurea accession used this time was the same as the parent, but the leaf color for accession 1 was different from the parent, which was light green. Differences in leaf color from the parent can be caused by environmental influences and fertilizer application. According to Pratiwi et al. (2019), changes in leaf color of Mentha spicata were caused by lack of sunlight and absorption of nutrients and water.

\section{Extraction}

Extraction of E. purpurea was carried out by maceration. The maceration method is a simple extraction method with the principle of immersing and stirring the sample in an appropriate solvent in extracting flavonoid compounds, and maceration extraction have the advantage 
of using more solvents than other extraction methods (Sapiun et al. 2020).

The ethanol extract of $E$. purpurea had a blackish green color that contains active ingredients. According to Mahajan et al. (2020), secondary metabolites were produced as one of the adaptive mechanisms of plants under stress conditions. Figure 4 shows the graph of extract from three accessions of $E$. purpurea treated with golden snail protein. The extract percentage of A1, A2, and A3 was $7.53 \%, 7.98 \%$, and $8.42 \%$, respectively. Application of golden snail protein produces various extract percentages ranging from $7.78 \%$ to $8.49 \%$. The addition of golden snail protein at high concentrations has a low extract yield. The might be due to the primary metabolic processes in the plant running well and not experiencing stress, therefore the plant produces only a small amount of secondary metabolites such as flavonoids. According to Tuteja (2007), the production of secondary metabolites in plants directly depends on the physiological conditions and development of these plants.

The extract yield is related to the chemical compounds contained in the plant. The high yield of extract does not correlate with the amount of specific active ingredients such as flavonoids because the herb extract is an accumulation of all the active ingredients contained in plants. The solvent used is ethanol which is polar which is used to extract polar components such as flavonoids. Further testing needs to be done to obtain more specific active ingredients or secondary metabolites. According to Mumtazah et al. (2020) stated that a high yield of extract does not necessarily produce high active ingredients.

\section{Total flavonoid content}

Flavonoids are one of the secondary metabolites that have been known to be contained in E. purpurea. According to Heldt (2011), flavonoids are a combination of organic pigments that form the color of leaves, flowers, stems, and fruit in plants and are also useful for humans, specifically as antioxidants. The biosynthesis of flavonoids is carried out through the phenylpropanoid pathway and involves PAL (Phenylalanine Ammonia-Lyase) enzyme (Taiz and Zeiger 2002).

Accession 2 in each treatment of golden snail protein showed the highest yield except in the treatment of 10 $\mathrm{mL} / \mathrm{l} /$ week. The highest flavonoid content in 3 accessions was found in the golden snail protein treatment at the concentration of $10 \mathrm{~mL} / \mathrm{l} /$ week. The concentration of 10 $\mathrm{mL} / \mathrm{L} /$ week increased the flavonoid content by $19 \%$ compared to the control treatment $(0 \mathrm{~mL} / \mathrm{L} /$ week $)$. The concentration of $0 \mathrm{~mL} / \mathrm{L} /$ week or control had the lowest flavonoid content (Figure 5). The application of golden snail protein more than $10 \%$ reduced the total flavonoid content compared to the $10 \%$ treatment. This is due to the higher the concentration of golden snail protein, the higher the nitrogen content. Nitrogen has an important role in plant growth. An adequate supply of nitrogen could result in good plant growth and a stable primary metabolic process so that primary metabolic products can be properly translocated throughout the plant body and the plant does not experience stress. Plants that grow well do not trigger Phenylalanine Ammonia Lyase (PAL) enzyme activity which plays an important role in the formation of flavonoids in the shikimate or phenylpropanoid pathway so that low PAL enzyme activity results in low flavonoid accumulation.

The low concentration of golden snail protein resulted in high total flavonoid content. The lower the concentration of golden snail protein, the lower the nitrogen content. According to the research of Ibrahim et al. (2011) nitrogen deficiency increases the accumulation and synthesis of phenolic compounds and flavonoids through the phenylpropanoid pathway. A study by Liu et al. (2010) showed that flavonoid content in $C$. morifolium leaves was high at low $\mathrm{N}$ supply.

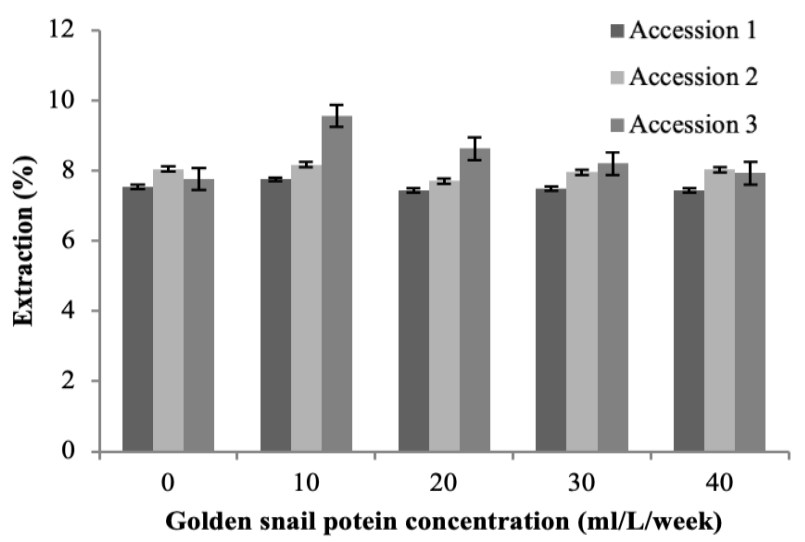

Figure 4. Percentage of extraction of three Echinacea purpurea accessions treated with different concentrations of golden snail protein

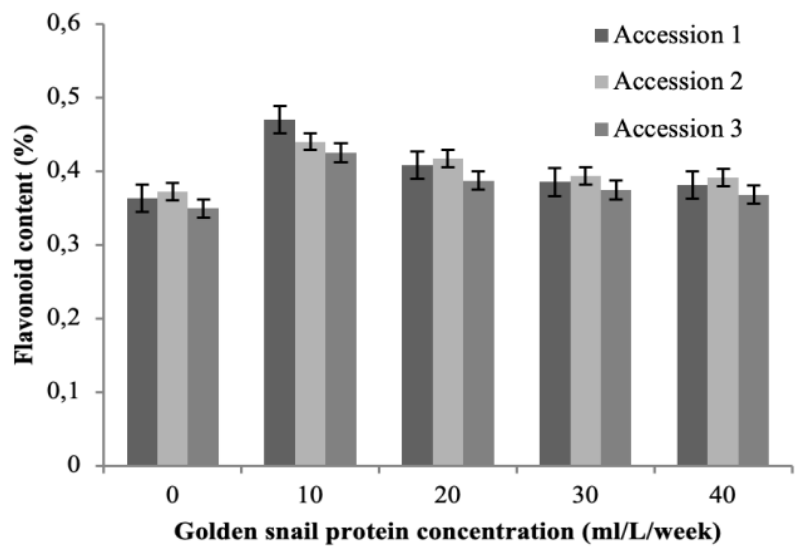

Figure 5. Total flavonoid content of three Echinacea purpurea accessions treated with different concentrations of golden snail protein 
The formation of flavonoids compounds in $E$. purpurea plants was caused by the plant experiencing nutritional stress, namely the lack of availability of nitrogen nutrients. Stress caused by plants will increase the activity of the enzyme PAL which plays a role in the formation of secondary metabolites through the phenylpropanoid pathway that produces phenols and their derivatives, namely flavonoids. According to Liu et al. (2010), the increase in PAL enzyme activity is an important mechanism that contributes to the increased accumulation of flavonoids. The control treatment had the lowest flavonoid content because the plants only utilized nutrients from the soil without the addition of a continuous supply of golden snail protein. The nitrogen available in the soil is limited and is used by plants for the growth process so that over time the availability of nitrogen runs out and plants cannot survive even though they have produced secondary metabolites. Low nitrogen availability causes inhibition of flavonoid biosynthesis.

In conclusion, there were differences in the morphological characteristics of the three accessions of $E$. purpurea in stem color, flower crown shape, and leaf shape. The highest total flavonoid content was found in Accession 2 and the highest extract yield was found in Accession 3. The concentration of golden snail protein 10 $\mathrm{mL} / \mathrm{L} /$ week could increase the flavonoid content by $19 \%$ compared to the control treatment $(0 \mathrm{~mL} / \mathrm{L} /$ week $)$.

\section{ACKNOWLEDGEMENTS}

The authors would like to thank the Research and Development Center for Medicinal Plants and Traditional Medicines (B2P2TOOT) in Tawangmangu, Central Java, Indonesia which has supported the accession of $E$. purpurea seeds, financially, and access for analysis in the laboratory.

\section{REFERENCES}

Aarland RC, Banuelos-Hernandez AE, Fragoso-Serrano M, SierraPalacios ED, de. Leon-Sanchez FD, Perez-Flores, Mendoza-Espinoza JA. 2017. Studies on phytochemical, antioxidant, anti-inflammatory, hypoglycaemic and antiproliferative activities of Echinacea purpurea and Echinacea angustifolia extracts Pharm Biol 55 (1): 649-656. DOI: $10.1080 / 13880209.2016 .1265989$.

Allen NS (ed.). 2010. Photochemistry and photophysics of polymeric materials. John Wiley \& Sons, New Jersey.

Andriani V. 2019. Application of golden snail (Pomacea canaliculata L.) as liquid organic fertilizer for melon (Cucumis melo L.) plant growth var. japonica. Symbiosis 8 (2): 100-108. DOI: 10.33373/simbio.v8i2.1968.

Bodinent C, Lindequist U, Teuscher E, Freudenstein J. 2002. Effect of an orally applied herbal immunomodulator on cytokine induction and antibody response in normal and immunosuppressed mice. Phytomedicine 9: 606-613. DOI: 10.1078/094471102321616418.
Chang CC, Yang MH, Wen HM, Chern JC. 2002. Estimation of total flavonoid content in propolis by two complementary colorimetric methods. J Food Drug Anal 10 (3): 178-182. DOI: 10.38212/22246614.2748 .

Choirunnisa JP, Widyastuti Y, Sakya AT, Yunus A. 2021. Morphological characteristics and flavonoid accumulation of Echinacea purpurea cultivated at various salinity. Biodiversitas 22 (9): 3716-3721. DOI: 10.13057/biodiv/d220915.

Frungillo L, Skelly MJ, Loake GJ, Spoel SH, Salgado I. 2014. Snitrosothiols regulate nitric oxide production and storage in plants through the nitrogen assimilation pathway. Nat Commun 5: 5401. DOI: $10.1038 /$ ncomms6401

Hajagha RI, Tabrizi L, Kafkas E, Kiric S. 2019. Evaluation of antioxidant activity and some secondary metabolites of purple coneflower (Echinacea purpurea L.) in response to biological and chemical fertilizers. J Agric Sci 11 (17): 1-10. DOI: 10.5539/jas.v11n17p1.

Heldt P. 2011. Plant Biochemistry. Academic Press, London.

Hertrampf JW, Piedad-Pascual F. 2000. Handbook on Ingredients for Aquaculture Feeds. Kluwer Academic Publishers, London.

Ibrahim MH, Jaafar HZE, Rahmat A, Rahman ZA. 2011. Effects of nitrogen fertilization on synthesis of primary and secondary metabolites in three varieties of kacip fatimah (Labisa pumila Blume). Intl J Mol Sci 12 (8): 5238-5254. DOI: 10.3390/ijms12085238.

Jintasataporn O, Tabthipwon P, Yenmark S. 2004. Substitution of golden apple snail meal for fish meal in giant freshwater prawn, Macrobrachium rosenbergii (de Man) diets. Kasetsart J Nat Sci 38: 66-71.

Lee TT, Huang CC, Shieh XH, Chen CL, Chen LJ, Yu B. 2010 Flavonoid, phenol and polysaccharide contents of Echinacea purpurea L. and its immunostimulant capacity in vitro. Intl J Environ Sci Develop 1 (1): 5-9. DOI: 10.7763/IJESD.2010.V1.2.

Liu W, Zhu DW, Liu DH, Geng MJ, Zhou WB, Mi WJ. 2010. Influence of nitrogen on the primary and secondary metabolism and synthesis of flavonoids in Chrysanthemum morifolium Ramat. J Plant Nutr 33: 240-254. DOI: 10.1080/01904160903434287.

Mahajan M, Kuiry R, Pal PK. 2020. Understanding the consequence of environmental stress for accumulation of secondary metabolites in medical and aromatic plants. J Appl Res Med Aromatic Plants 18: 100255. DOI: 10.1016/j.jarmap.2020.100255.

Mumtazah HM, Supriyono, Widyastuti Y, Yunus A. 2020. The diversity of leaves and asiaticoside content on three accessions of Centella asiatica with the addition of chicken manure fertilizer. Biodiversitas 21 (3): 1035-1040. DOI: 10.13057/biodiv/d210325.

Pratiwi PY, Mardiyaningsih A, Widarti E. 2019. Differences in the quality of hydroponic and conventional mint (Mentha spicata L) plants based on plant morphology, chromatogram profile, and essential oil content. Jurnal Riset Kefarmasian Indonesia 1 (2): 148-156. [Indonesian]

Rahardjo M. 2000. Echinacea potential introduced medicinal plants. Warta Penelitian dan Pengembangan Tanaman Industri 6 (2): 1-3. [Indonesian]

Rahardjo M. 2005. Opportunities for cultivation of echinacea (Echinacea purpurea) in Indonesia. Perspective 4 (1): 1-10. [Indonesian]

Sabiun Z, Pangalo P, Imran AK, Wicita PS, Daud RPA. 2020. Determination of total flavonoid levels of ethanol extract sesewanua leaf (Clerodendrum fragrans Wild) with maceration method using UV-Vis spectrophotometry. Pharmacogn J 12 (2): 356-360. DOI: 10.5530/pj.2020.12.56.

Shidiq DF, Widyastuti Y, Subositi D, Pujiasmanto B, Yunus A. 2020. Morphological diversity, total phenolic and flavonoid content of Echinacea purpurea cultivated in Karangpandan, Central Java, Indonesia. Biodiversitas 21 (3): 1265-1271. DOI: 10.13057/biodiv/d210355

Taiz L, Zeiger E. 2002. Plant Physiology $3^{\text {rd }}$ edn. Sinauer Associates, Sunderland, Tyne and Wear, England.

Tuteja N. 2007. Mechanisms of high salinity tolerance in plants. Methods in Enzymology 428: 419-438. DOI: 10.1016/S0076-6879(07)280243. 